\title{
ANALISIS PENDAPATAN MASYARAKAT DAN BAGI HASIL (MUDHARABAH) TERHADAP MINAT MASYARAKAT MENABUNG PADA PT. BANK MUAMALAT INDONESIA TBK CABANG PEKANBARU
}

\author{
Wenny Desty Febrian* \\ * Fakultas Ekonomi dan Ilmu Sosial, \\ Universitas Islam Negeri Sultan Syarif Kasim Riau \\ Jl. HR. Soebrantas Panam KM 15 No.155 tampan Pekanbaru, 28293 \\ Email: wenny.sani27@gmail.com
}

\begin{abstract}
Abstrak: PT. Bank Muamalat Indonesia Tbk Cabang Pekanbaru adalah salah satu bank syariah yang ada dikota Pekanbaru yang menerapkan sistem bagi hasil kepada nasabahnya. Tujuan dari penelitian ini adalah untuk mengetahui apakah pendapatan masyarakat dan sistem bagi hasil (Mudharabah) dapat mempengaruhi minat masyarakat menabung atau lebih dominan dipengaruhi oleh faktor-faktor yang lain. Metode yang digunakan adalah metode kuantitatif, yaitu dengan menggunakan bantuan jawaban dari kuesioner dan kemudian diolah dengan SPSS seri 16, setelah itu membuat kesimpulan dari data yang diperoleh tersebut. Selain itu, metode wawancara juga dibutuhkan dalam membantu menyelesaikan penulisan ini. Dari data yang ada, diperoleh hasil bahwa kebanyakan responden menyatakan bahwa pendapatan masyarakat dan bagi hasil (Mudharabah) mempengaruhi minat mereka untuk menabung. Sementara faktor-faktor lain hanya sedikit sekali mempengaruhi minat menabung. Dari penelitian yang dilaksanakan dapat diperoleh kesimpulan bahwa pendapatan masyarakat dan bagi hasil (Mudharabah) dapat mempengaruhi minat masyarakat menabung pada PT. Bank Muamalat Indonesia Tbk Cabang Pekanbaru.
\end{abstract}

Kata Kunci : Pendapatan Masyarakat, Bagi Hasil (Mudharabah), Bank Muamalat Indonesia 


\section{PENDAHULUAN}

Sebelum pasar barang dan jasa berkembang seperti saat ini, kegiatan transaksi dilaksanakan dengan cara yang lebih sederhana. Sejalan dengan berkembangnya pelaku ekonomi dan kebutuhan penggunaan uang dalam kegiatan ekonomi, kehadiran perantara baik secara lembaga atau fisik menjadi sesuatu yang penting dalam perekonomian. Perantara ini dikenal dengan lembaga keuangan. Berkembangnya dunia usaha saat ini telah banyak melahirkan lembagalembaga keuangan baru, terutama dibidang perbankan. Hal ini menuntut suatu kegiatan dan pelaporan ekonomi yang dilaksanakan lembaga perbankan tersebut dan haruslah dilaksanakan dengan menyajikan laporanlaporan keuangan secara benar, agar dapat memenuhi pengguna laporannya. Salah satu lembaga perbankan yang hangat menjadi topik pembicaraan dalam beberapa tahun belakangan ini adalah perbankan syariah, lembaga keuangan dibidang pebankan yang berazaskan Islam. Banyak yang mengatakan pasar syariah adalah pasar yang emosional (emotional market) sedangkan pasar konvensional adalah pasar yang rasional (rational market). Maksudnya disini orang tertarik untuk berbisnis pada pasar syariah karena alasan-alasan keagamaan (dalam hal ini agama Islam) yang lebih bersifat emosional, bukan karena ingin mendapatkan keuntungan financial yang bersifat rasional. Sebaliknya, pada pasar konvensional atau non-syariah, orang ingin mendapatkan keuntungan yang sebesar-besarnya, tanpa terlalu peduli apakah bisnis yang digelutinya tersebut mungkin menyimpang atau malah bertentangan dengan ajaran agama Islam. Pada penerapan sistem syariah, tentu mempunyai sistem perlakuan yang berbeda dengan perlakuan konvensional pada umumnya, salah satunya kebutuhan dalam menetapkan metode pembiayaan Mudharabah harus disesuaikan dengan peraturan perbankan dan ketentuan-ketentuan syariah yang telah diatur. Salah satu perbankan syariah yang ada yaitu PT. Bank Muamalat. Secara resmi PT. Bank Muamalat Cabang Pekanbaru beroperasi di pusat kota Pekanbaru. Dalam kegiatan usahanya PT. Bank Muamalat memiliki jenis simpanan seperti tabungan Ummat, Ummat Junior, Shar-E, dan Arafah.

Jumlah penabung pada PT. Bank Muamalat Cabang Pekanbaru dapat dilihat dalam tabel sebagai berikut:

Tabel 1. Jumlah Nasabah PT. Bank Muamalat Indonesia (Satuan Orang)

\begin{tabular}{|l|c|c|c|c|c|}
\hline \multicolumn{1}{|c|}{ Tabungan } & 2014 & 2015 & 2016 & 2017 & 2018 \\
\hline Ummat & 4.875 & 5.487 & 5.842 & 6.234 & 6.586 \\
\hline Ummat Junior & 989 & 1.161 & 1.329 & 1.598 & 1.868 \\
\hline Shar-E & 33.187 & 42.573 & 37.654 & 39.135 & 35.592 \\
\hline Arafah & 1.958 & 2.164 & 2.364 & 2.356 & 2.654 \\
\hline Jumlah & 41.009 & 51.385 & 41.099 & 49.323 & 46.700 \\
\hline
\end{tabular}

Sumber :PT.. Bank Muamalat Indonesia Tbk cabang Pekanbaru

SYARIKAT : Jurnal Rumpun Ekonomi Syariah Volume 1, Nomor 2, Desember 2018 
Dari tabel diatas, dapat dilihat bahwa pada PT. Bank Muamalah Cabang Pekanbaru jumlah penabung pada produk tabungan Ummat yang pada tahun 2014 berjumlah 4.875 nasabah lalu tahun 2015 berjumlah 5.487 nasabah (meningkat) dan pada tahun 2016 mencapai jumlah 5.842 nasabah (meningkat), tahun 2017 dengan 6.243 nasabah (meningkat) lalu tahun 2018 mencapai 6.586 jumlah nasabah (meningkat). Pada tabungan Ummat Junior pada tahun 2014 memiliki 989 nasabah lalu tahun 2015 memiliki 1.161 nasabah (meningkat), pada tahun 2016 mencapai 1.329 jumlah nasabah (meningkat) tahun 2017 memiliki 1.598 nasabah (meningkat) dan pada tahun 2018 memiliki 1.868 jumlah nasabah (meningkat). Pada tabungan Shar-E ditahun 2014 mencapai. 33.187 nasabah, ditahun 2015 jumlah nasabah sebesar 35.592 penabung (meningkat), lalu pada tahun 2016 mencapai 37.564 nasabah (meningkat), pada tahun 2017 dengan jumlah 39.135 nasabah (meningkat), lalu pada tahun 2018 penabung Shar-E mencapai 42.573 nasabah (meningkat). Pada tabungan Arafah tahun 2014 memiliki 1.958 nasabah lalu pada tahun 2015 dengan 2.164 nasabah (meningkat), pada tahun 2016 dengan 2.364 nasabah (meningkat), pada tahun 2017 dengan jumlah 2.654 nasabah (meningkat), pada tahun 2018 mengalami penurunan jumlah nasabah menjadi 2.356 penabung (menurun).

Melihat dan menganalisis uraian di atas penulis tertarik untuk meneliti lebih lanjut tentang minat masyarakat menabung pada PT. Bank Muamalat Indonesia Tbk cabang Panam Pekanbaru dengan judul: "Pengaruh Pendapatan Masyarakat dan Tingkat Bagi Hasil Mudharabah) Terhadap Minat Masyarakat Menabung
Pada PT.. Bank Muamalat Indonesia Tbk Cabang Pekanbaru".

\section{Perumusan Masalah}

Berlandaskan pada latar belakang yang telah dikemukakan di atas maka penulis merumuskan permasalahan sebagai berikut: "Apakah pendapatan masyarakat dan tingkat bagi hasil (Mudharabah) mempengaruhi minat masyarakat untuk menabung pada PT. Bank Muamalat Indonesia Tbk Cabang Pekanbaru?"

\section{Tujuan dan Manfaat Penelitian Tujuan Penelitian}

Sesuai dengan permasalahan yang dikemukakan diatas, maka tujuan dari penelitian ini adalah : Untuk mengetahui pengaruh tingkat pendapatan masyarakat dan tingkat bagi hasil terhadap minat masyarakat untuk menabung pada PT. Bank Muamalat Tbk Cabang Pekanbaru.

\section{Manfaat Penelitian}

Hasil penelitian ini diharapkan dapat bermanfaat sebagai:

a. Hasil penelitian diharapkan dapat bermanfaat bagi PT. Bank Muamalat Tbk Cabang Pekanbaru sebagai bahan pertimbangan dalam meningkatkan kinerjanya serta dapat memperbaiki kesalahankesalahan di tahun-tahun sebelumnya yang mengakibatkan penurunan jumlah nasabah.

b. Hasil penelitian diharapkan dapat memberikan informasi dan masukan bagi masyarakat yang tertarik terhadap PT. Bank Muamalat Tbk Cabang Pekanbaru dan sebagai bahan referensi bagi 
para peneliti selanjutnya yang tertarik di bidang ini.

c. Hasil penelitian diharapkan dapat dijadikan sebagai penambah wawasan dan ilmu pengetahuan bagi penulis mengenai perbankan syariah, khususnya PT. Bank Muamalat Indonesia Cabang Pekanbaru ini.

\section{TINJAUAN PUSTAKA}

\section{Teori Bank}

Bank adalah (kasmir, 2007: 8) lembaga keuangan yang menjadi lembaga perantara antara masyarakat yang kelebihan dana dan masyarakat yang kekurangan dana. Bagi masyarakat yang kelebihan dana dapat menyimpan uangnya dalam bentuk simpanan giro, tabungan, deposito, atau bentuk simpanan lainnya. Begitu pula masyarakat yang kekurangan dana dapat meminjam uang dilembaga keuangan dalam bentuk kredit.

Dilihat dari segi menentukan harga, baik harga jual maupun harga beli. Bank Indonesia terbagi dalam dua kelompok, yaitu (Kasmir, 2002: 37-38):

1. Bank yang bedasarkan prinsip konvensional

Mayoritas bank yang berkembang di Indonesia adalah bank yang berorientasi pada prinsip konvensional. Hal ini tidak terlepas dari sejarah bangsa Indonesia dimana asal mula bank di Indonesia dibawa oleh kolonial Belanda.

2. Bank yang berasarkan prinsip syariah

Bank bedasarkan prinsip syariah belum lama berkembang di
Indonesia. Namun di luar negeri terutama di negara-negara Timur Tengah bank yang berdasarkan prinsip syariah sudah berkembang pesat sejak lama.

Untuk lebih jelasnya Nugroho (2003: 75) memaparkan ciri-ciri bank syariah sebagai berikut:

1. Melakukan investasi yang halalhalal saja. Uang simpanan yang berasal dari pihak ketiga harus diinvestasikan pada kegiantan yang jelas halal dan tidak melakukan investasi pada kegiatan yang diragukan kehalalannya, apalagi yang haram.

2. Bedasarkan prinsip bagi hasil, jual beli atau sewa dan tidak memakai perangkat bunga. Semua produk bank syariah harus bersih dari unsur bunga.

3. Profit dan falah oriented. Falah oriented merupakan mencari kemakmuran dan kebahagiaan baik di dunia maupun di akhirat.

4. Hubungan dengan nasabah berbentuk kemitraan. Tidak sematamata hubungan kerditur-debitur seperti yang terjadi pada bank-bank konvensional.

5. Penghimpunan dan penyaluran dana harus sesuai dengan fatwa dewan pengawas syariah yang akan melakukan tugas pengawasan agar produk tidak mengandung unsur bunga, sedangkan pada bank konvensional dewan ini tidak ada. 
Produk Penghimpunan Dana (Funding)

Penghimpunan dana di bank syariah dapat berbentuk tabungan, giro, dan deposito. Prinsip opersional syariah yang diterapkan dalam penghimpunan dana masyarakat adalah prinsip Wadiah dan Mudharabah.

1) Prinsip Wadiah

Prinsip Wadiah yang diterapkan adalah Wadiah yad dhamamah yang diterapkan pada produk giro. Dimana pihak bank bertanggung jawab atas keutuhan harta titipan sehingga bank boleh memanfaatkan harta titipan tersebut.

2) Prinsip Mudharabah.

Produk Mudharabah disini pihak bank bertindak sebagai pengelola dana sedangkan pihak nasabah sebagai pemilik dana. Adapun gambar pada tabungan Mudharabah dapat dilihat pada gambar sebagai berikut:

\section{Gambar 1 : Mudharabah pada penghimpunan dana}

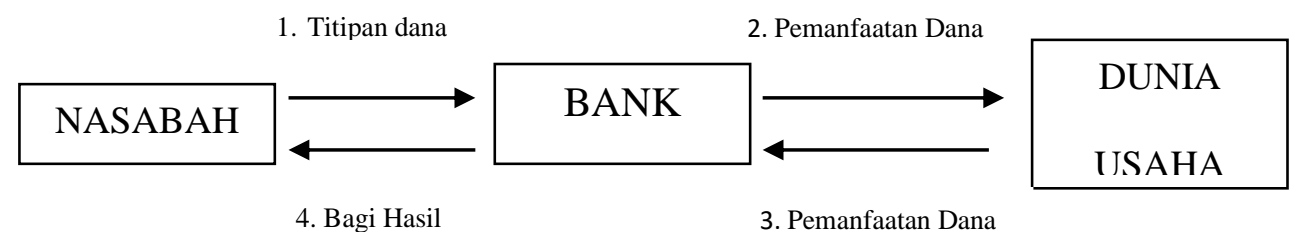

Sumber : wirdyaningsih dkk, $2006: 105$

\section{Pendapatan}

Menurut Sukirno (2004: 49) pendapatan sebagai penghasilan yang diperoleh dari jasa-jasa produksi yang dihasilkan pada suatu waktu tertentu. Menurut Sukirno (2004: 60-61) bahwasanya pendapatan nasional adalah nilai produksi barang-barang dan jasa yang dihasilkan (diwujudkan) dalam suatu Negara dalam suatu tahun tertentu dan pendapatan pribadi dapat diartikan sebagai semua jenis pendapatan, termasuk pendapatan yang diperoleh tanpa memberikan sesuatu kegiatan apapun, yang diterima oleh penduduk suatu Negara. Sedangkan pendapatan disposibel adalah pendapatan pribadi yang dikurangi oleh pajak dan harus dibayar oleh penerima pendapatan, dan nilai yang tersisa itulah yang disebut sebagai pendapatan disposibel. Pendapatan merupakan penjumlahan pengeluaran konsumsi rumah tangga plus investasi, atau juga yang berbentuk sisa pendapatan sesudah dikurangi dengan seluruh pengeluaran konsumsi rumah tangga merupakan saving rumah tangga.

Berdasarkan uraian di atas dapat dikemukakan bahwa semakin tinggi pendapatan seseorang, maka semakin tinggi pula tingkat saving atau tabungannya. Masyarakat yang berpendapatan tinggi pada umumnya mempunyai tabungan yang tinggi begitu juga sebaliknya masyarakat yang berpendapatan rendah mempunyai tabungan yang rendah. Keinginan untuk menabung ditentukan oleh keadaan perekonomian masyarakat itu sendiri.

SYARIKAT : Jurnal Rumpun Ekonomi Syariah Volume 1, Nomor 2, Desember 2018 
Menurut UU. RI No. 10 tahun 1998, tabungan adalah simpanan yang penarikannya hanya dapat dilakukan menurut syarat tertentu yang disepakati tetapi tidak dapat ditarik dengan menggunakan cek atau alat lainnya yang dapat dipersamakan dengan itu.

Indikator yang perlu diperhatikan untuk menarik atau merangsang masyarakat atau perusahaan agar menabung pada banknya adalah (Sumarni, 2002: 31):

1. Kepercayaan

2. Pelayanan

3. Lokasi dan Keamanan

4. Kebersihan dan kenyamanan

5. Promosi

6. Kebijakan tabungan

\section{Bagi Hasil}

Bagi hasil menurut terminology asing (inggris) dikenal dengan profit sharing. Profit sharing dalam kamus ekonomi diartikan pembagian laba. Secara definitive profit sharing didefinisikan (Muhammad, 2001: 90) distribusi beberapa bagian dari laba pegawai dari suatu perusahaan hal itu dapat berbentuk suatu bonus uang tunai tahunan yang didasarkan pada laba yang diperoleh pada tahun-tahun sebelumnya, atau dapat berbentuk pembayaran mingguan atau bulanan.

Bank syariah dalam usahanya memberikan pembiayaan dan jasa lainnya selalu berlandaskan pada prinsip syariah, antara lain dengan tidak menggunakan sistem bunga untuk aktivitas perbankannya. Karena bunga merupakan jenis riba yang diharamkan dalam Islam. Hal ini sesuai dengan yang disebutkan dalam Al-Qur'an Surat Al-Baqarah ayat 278-279 yang artinya "Wahai orang-orang yang beriman, bertaqwalah kepada Allah dan tinggalkanlah sisa-sisa riba, jika kamu orang-orang yang beriman. Maka jika kamu tidak mengerjakan (perintah itu), maka ketahuilah bahwa Allah dan Rasul-Nya akan memerangimu. Dan jika kamu bertaubat, maka bagimu pokok hartamu, kamu tidak menganiaya dan tidak (pula) dianiaya".

Dari ayat di atas telah di jelaskan riba merupakan salah satu hal yang dilarang dalam Islam, karena juga termasuk dalam kategori mengambil atau memperoleh harta dengan cara yang tidak benar. Perbedaan bunga dan bagi hasil dapat dilihat dari tabel berikut:

\section{Tabel 2. Perbedaan Bunga dan Bagi Hasil}

\begin{tabular}{|c|c|}
\hline BUNGA & BAGI HASIL \\
\hline $\begin{array}{l}\text { 1. Penentuan bunga dibuat pada } \\
\text { waktu akad dengan asumsi usaha } \\
\text { akan selalu mengahasilkan } \\
\text { keuntungan }\end{array}$ & $\begin{array}{l}\text { Penentuan besarnya rasio/ nisbah } \\
\text { bagi hasil desepakati pada waktu } \\
\text { akad dengan berpedoman pada } \\
\text { kemungkinan untung rugi }\end{array}$ \\
\hline $\begin{array}{l}\text { 2. Besarnya persentase didasarkan } \\
\text { pada jumlah dana/ modal yang di } \\
\text { pinjamkan. }\end{array}$ & $\begin{array}{l}\text { Besarnya rasio bagi hasil didasarkan } \\
\text { pada jumlah keuntungan yang } \\
\text { diperoleh }\end{array}$ \\
\hline $\begin{array}{l}\text { 3. Bunga dapat berkembang } \\
\text { jumlahnya, dan besarnya naik } \\
\text { turun sesuai dengan naik turunya }\end{array}$ & $\begin{array}{l}\text { Rasio bagi hasil tetap tidak berubah } \\
\text { selama akad masih berlaku, kecuali } \\
\text { diubah atas kesepakatan bersama. }\end{array}$ \\
\hline
\end{tabular}

SYARIKAT : Jurnal Rumpun Ekonomi Syariah Volume 1, Nomor 2, Desember 2018 


\begin{tabular}{|c|c|c|}
\hline & $\begin{array}{l}\text { bunga patokan atau kondisi } \\
\text { ekonomi. }\end{array}$ & \\
\hline 4. & $\begin{array}{l}\text { Pembayaran bunga tetap seperti } \\
\text { yang telah dijanjikan tanpa } \\
\text { pertimbangan apakah usaha yang } \\
\text { dijalankan peminjam untung atau } \\
\text { rugi. }\end{array}$ & $\begin{array}{l}\text { Bagi hasil bergantung pada } \\
\text { keuntungan usaha yang dijalankan. } \\
\text { Bila merugi, kerugian akan } \\
\text { ditanggung bersama. }\end{array}$ \\
\hline & $\begin{array}{l}\text { Jumlah pembayaran bunga tidak } \\
\text { meningkat sekalipun keuntungan } \\
\text { naik berlipat ganda. }\end{array}$ & $\begin{array}{l}\text { Jumlah pembagian laba meningkat } \\
\begin{array}{l}\text { sesuai dengan } \\
\text { keuntungan. }\end{array}\end{array}$ \\
\hline
\end{tabular}

1. Para mitra usaha bebas menentukan, dengan persetujuan bersama, rasio keuntungan untuk masing-masing pihak, yang dapat berbeda dari rasio pembiayaan yang disertakan.

2. Kerugian yang ditanggung oleh masing-masing pihak harus sama dengan proporsi investasi mereka.

\section{Minat}

Minat tidak dibawa dari lahir, melainkan diperoleh kemudian sebagai akibat rangsangan atau adanya suatu hal yang menarik, dimana suatu objek tersebut dapat memberikan keuntungan kepada diri seseorang. Minat juga akan tumbuh apabila ada perhatian (attention) terhadap objek tersebut. Salah satu faktor yang mempengaruhi minat terhadap produk adalah selera konsumen. Selera konsumen yang beraneka ragam dan minat terhadap produk ini akan timbul apabila produk tersebut memenuhi seleranya dan juga dapat memberikan kepuasan.

\section{Hipotesis}

Dari perumusan masalah yang telah dikemukakan diatas, maka penulis menarik kesimpulan sementara yang dapat diajukan sebagai hipotesis yakni: diduga bahwa pendapatan masyarakat dan tingkat bagi hasil dapat mempengaruhi minat masyarakat untuk menabung pada PT. Bank Muamalat Indonesia Tbk Cabang Pekanbaru.

\section{Variabel Penelitian}

Adapun yang menjadi variabel penelitian ini adalah :

Variabel terikat(Dependen) : $\quad$ Minat Masyarakat (Nasabah) (Y)

Variabel bebas (Independen) :

Pendapatan Masyarakat(Nasabah)

Tingkat Bagi Hasil (Mudharabah) (X2)

\section{METODE}

\section{Lokasi Penelitian}

Penelitian dilakukan pada PT. Bank Muamalat Cabang Pekanbaru yang berlokasi dijalan sudirman, Pekanbaru. 


\section{Teknik Pengumpulan Data}

Teknik pengumpulan data dalam penelitian ini bedasarkan metode accidental, untuk data primer dan sekunder adalah dengan menggunakan Kuesioner, Interview dan Observasi.

\section{Populasi dan Sampel}

Populasi dalam penelitian ini adalah seluruh penabung yang terdiri dari Tabungan Ummat, Tabungan Ummat Junior, Tabungan Shar-E, Tabungan Arafah yang berjumlah 46.700 orang. Sedangkan sampel merupakan bagian dari populasi dan besarnya sampel yang diambil dalam penelitian ini adalah dengan menggunakan perumusan Slovin yakni: (Umar, 2002: 9697).

Dalam penelitian ini, peneliti mengambil nilai $10 \%$ untuk standar error nya (e) maka sampel yang diperlukan adalah:

$$
\begin{aligned}
& \mathrm{n}=\frac{46.700}{\left\{1+46.700(10 \%)^{2)}\right.} \\
& \mathrm{n}=\frac{46.700}{468} \\
& \mathrm{n}=99,786 \text { (dibulatkan menjadi } 100 \text { orang } \\
& \text { nasabah) }
\end{aligned}
$$

\section{Jenis Simpanan dan Jumlah Nasabah}

Secara resmi PT. Bank Muamalat Indonesia Tbk Cabang Pekanbaru beroperasi di pusat kota Pekanbaru. Dalam kegiatann usahanya PT. Bank Muamalat memiliki jenis simpanan. Untuk lebih jelasnya perincian jenis simpanan dan jumlah nasabah pada PT. Bank Muamalat Indonesia Tbk Cabang Pekanbaru, dapat dilihat pada tabel dibawah ini berkisar dari tahun 2014 sampai 2018:

Tabel 3. Jenis Simpanan dan Jumlah Nasabah PT. Bank Muamalat

\begin{tabular}{|c|r|r|r|r|r|}
\hline \multirow{2}{*}{$\begin{array}{c}\text { Jenis Sim } \\
\text { Panan }\end{array}$} & \multicolumn{5}{|c|}{ Jumlah Nasabah (Orang) } \\
\cline { 2 - 6 } & 2014 & 2015 & 2016 & 2017 & 2018 \\
\hline Tabungan : & & & & & \\
a. Tabungan Ummat & 4.875 & 5.487 & 5.842 & 6.243 & 6.586 \\
b. Tabungan Ummat & 989 & 1.161 & 1.329 & 1.598 & 1.868 \\
$\quad$ Junior & & & & & \\
c. Tabungan Shar-E & 33.187 & 33.187 & 37.564 & 39.135 & 42.573 \\
d. Tabungan Arafah & 1.958 & 1.958 & 2.164 & 2.654 & 2.356 \\
\hline
\end{tabular}

Sumber : PT. Bank Muamalat Indonesia Tbk Cabang Pekanbaru, 2018

Pertambahan jumlah nasabah yang menabung pada tabungan Ummat tahun 2014 sebesar 4.875 penabung, tahun 2015 naik sebesar $12.56 \%$ dengan 5.487 penabung. Tahun 2016 kenaikannya sebesar $6,47 \%$ dengan 5.842 penabung dan tahun 2017 dengan 6.243 penabung naik mencapai 6,87\%. Tahun 2018 mengalami peningkatan yang cukup tinggi sebesar $5,50 \%$ dengan 6.586 penabung. Pada tabungan Ummat Junior, tahun 2014 jumlah nasabahnya 989 penabung, tahun 2015 naik sebesar 17,40\% dengan 1.161 nasabah. Tahun 2016 naik sebesar 14,48\% dengan nasabah 1.329 nasabah.

SYARIKAT : Jurnal Rumpun Ekonomi Syariah Volume 1, Nomor 2, Desember 2018 
Tahun 2017 dengan 20,25\% dan tahu 2018 naik sebesar 16,90\% dengan jumlah nasabah 1.868. Pada tabungan Shar-E, tahun 2014 berjumlah 33.187 penabung, tahun 2015 kenaikan sebesar 7,25\% dengan 35.592 jumlah penabung lalu tahun 2016 mengalami kenaikan sebesar 5,54\% dengan 37.564 jumlah penabung. Tahun 2017 naik sebesar 4,91\% dengan 39.135 penabung dan tahun 2018 dengan 45.573 penabung. Pada tabungan arafah turun sebesar 11,2 \% yaitu dari 2.654 ke 2.356 .

HASIL

\section{Pengujian Kualitas Data}

Setelah data terkumpul, langkah selanjutnya yaitu melakukan uji kualitas data yaitu menguji normalitas data, validitas data, dan reabilitas data yang digunakan.

\section{a) Normalitas Data (Uji Kolmogorov- Smirnov)}

Uji normalitas adalah langkah awal yang harus dilakukan, untuk menguji normalitas data digunakan uji KolmogorovSmirnov, criteria yang digunakan adalah jika masing-masing variabel menghasilkan nilai K-S-Z dengan $\mathrm{P}>0,05$ maka dapat disimpulkan bahwa masing-masing data pada variabel yang diteliti terdistribusi secara normal. Hasil uji normalitas disajikan sebagai berikut:

Tabel 4. Hasil Uji Normalitas

\begin{tabular}{|l|l|r|r|r|}
\hline \multicolumn{5}{|c|}{ One-Sample Kolmogorov-Smirnov Test } \\
\hline & & \multicolumn{1}{|c|}{ TPM } & \multicolumn{1}{c|}{ TMD } & \multicolumn{1}{c|}{ TMM } \\
\hline \multicolumn{2}{|c|}{$\mathrm{N}$} & 100 & 100 & 100 \\
\hline Normal Parameters ${ }^{\mathrm{a}}$ & Mean & 21.5100 & 20.0500 & 21.0000 \\
\cline { 2 - 6 } & Std. Deviation & 2.40578 & 2.64145 & 2.14146 \\
\hline $\begin{array}{l}\text { Most Extreme } \\
\text { Differences }\end{array}$ & Absolute & .185 & .118 & .120 \\
\cline { 2 - 6 } & Positive & .185 & .118 & .110 \\
\cline { 2 - 6 } & Negative & -.152 & -.103 & -.120 \\
\hline Kolmogorov-Smirnov Z & 1.849 & 1.176 & 1.203 \\
\hline Asymp. Sig. (2-tailed) & .002 & .126 & .111 \\
\hline a. Test distribution is Normal. & & & \\
Sumber: Pengolahan Data Hasil Penelitian, 2018 & & \\
\hline
\end{tabular}

Dari tabel 4 dapat dilihat bahwa data nilai signifikan TPM (Pendapatan Masyarakat) sebesar 0,002, dan untuk variabel TMD (Mudharabah) sebesar 0,126, dan untuk TMM (Minat Masyarakat) 0,111.
Maka dapat disimpulkan bahwa data pada variabel TPM (Pendapatan Masyarakat), TMD (Mudharabah) dan TMM (Minat Masyarakat) berdistribusi normal.

SYARIKAT : Jurnal Rumpun Ekonomi Syariah Volume 1, Nomor 2, Desember 2018 


\section{b) Uji Validitas}

Setelah dilakukan uji normalitas langkah selanjutnya yaitu menguji validitas data. Pengujian ini akan menentukan layaknya data untuk dianalisis lebih lanjut. Berdasarkan uji validitas instrument penelitian yang dilakukan perhadap seluruh item pernyataan yang ditetapkan dalam penelitian ini adalah valid, oleh karna itu koesionernya layak digunakan sebagai instrument penelitian. Untuk mengetahui valid suatu variabel, masingmasing butir pernyataan dapat dilihat kevalidannya dari corrected rem-total correlation. Koesioner dapat dikatakan valid jika corrected rem-total correlation memiliki nilai > dari 0,3 atau 30\%. Hasil uji validitas data disajikan sebagai berikut:

Tabel 5. Hasil Uji Validitas Pendapatan Masyarakat(X1)

\begin{tabular}{|l|c|c|c|c|}
\hline \multicolumn{5}{|c|}{ Item-Total Statistics } \\
\hline & $\begin{array}{c}\text { Scale Mean if } \\
\text { Item Deleted }\end{array}$ & $\begin{array}{c}\text { Scale Variance } \\
\text { if Item Deleted }\end{array}$ & $\begin{array}{c}\text { Corrected Item- } \\
\text { Total Correlation }\end{array}$ & $\begin{array}{c}\text { Alpha if Item } \\
\text { Deleted }\end{array}$ \\
\hline X11 & 17.0800 & 3.893 & .725 & .796 \\
\hline X12 & 17.2900 & 3.339 & .782 & .774 \\
\hline X13 & 17.1800 & 4.493 & .474 & .854 \\
\hline X14 & 17.1800 & 4.250 & .517 & .846 \\
\hline X15 & 17.3100 & 3.267 & .785 & .773 \\
\hline
\end{tabular}

Sumber: Pengolahan Data Hasil Penelitian, 2018

Setelah dilakukan uji validitas pada variabel Pendapatan Masyarakat terlihat bahwa semua item variabel memenuhi syarat validitas karma memiliki korelasi >0,30.

Tabel 6. Hasil Uji Validitas Tingkat Bagi Hasil (X2)

\begin{tabular}{|l|r|r|r|r|}
\hline \multicolumn{5}{|c|}{ Item-Total Statistics } \\
\hline & $\begin{array}{c}\text { Scale Mean if } \\
\text { Item Deleted }\end{array}$ & $\begin{array}{c}\text { Scale Variance } \\
\text { if Item Deleted }\end{array}$ & $\begin{array}{c}\text { Corrected } \\
\text { Item-Total } \\
\text { Correlation }\end{array}$ & $\begin{array}{c}\text { Cronbach's Alpha if } \\
\text { Item Deleted }\end{array}$ \\
\hline X21 & 16.3200 & 3.614 & .629 & .604 \\
\hline X22 & 15.9200 & 5.084 & .409 & .698 \\
\hline X23 & 16.1200 & 5.460 & .423 & .695 \\
\hline X24 & 16.2100 & 4.168 & .588 & .623 \\
\hline X25 & 15.6300 & 5.569 & .382 & .707 \\
\hline
\end{tabular}

Sumber: Pengolahan Data Hasil Penelitian, 2018

SYARIKAT : Jurnal Rumpun Ekonomi Syariah Volume 1, Nomor 2, Desember 2018 
Setelah dilakukan uji validitas pada variabel Mudharabah terlihat bahwa semua item variabel memenuhi syarat validitas karma memiliki korelasi > 0,30.

Tabel 7. Hasil Uji Validitas Minat Masyarakat

\begin{tabular}{|l|r|r|r|rr|}
\hline \multicolumn{7}{|c|}{ Item-Total Statistics } \\
\hline & $\begin{array}{c}\text { Scale Mean if } \\
\text { Item Deleted }\end{array}$ & $\begin{array}{c}\text { Scale } \\
\text { Variance if } \\
\text { Item Deleted }\end{array}$ & $\begin{array}{c}\text { Corrected } \\
\text { Item-Total } \\
\text { Correlation }\end{array}$ & $\begin{array}{c}\text { Cronbach's Alpha if Item } \\
\text { Deleted }\end{array}$ \\
\hline Y11 & 16.6900 & 2.822 & .619 & .684 \\
\hline Y12 & 16.9700 & 3.262 & .453 & .745 \\
\hline Y13 & 16.7300 & 2.805 & .706 & .653 \\
\hline Y14 & 16.8100 & 3.287 & .481 & .735 \\
\hline Y15 & 16.8000 & 3.374 & .404 & .761 \\
\hline
\end{tabular}

Sumber : Pengolahan Data Hasil Penelitian, 2018

Setelah dilakukan uji validitas pada variabel Minat Masyarakat terlihat bahwa semua item variabel memenuhi syarat validitas karma memiliki korelasi > 0,30.

\section{c) Uji Reliabilitas}

Pengujian reliabilitas ini menggunakan Cronbach Alpha dengan taksiran batasan minimal 0,60. Berikut ini menerangkan hasil pengujian reliabilitas untuk setiap variabel dalam penelitian ini.

Tabel 8. Hasil Uji Reliabilitas Pendapatan Masyarakat (X1)

\begin{tabular}{|c|c|}
\hline \multicolumn{2}{|c|}{ Reliability Statistics } \\
\hline $\begin{array}{l}\text { Cronbach's } \\
\text { Alpha }\end{array}$ & $\mathrm{N}$ of Items \\
\hline .8 & \\
\hline
\end{tabular}

Sumber: Pengolahan Data Hasil Penelitian, 2018

Setelah dilakukan pengujian reliabilitas pada variabel Pendapatan Masyarakat terlihat bahwa koefisien reliabilitas instrument Pendapatan Masyarakat memenuhi syarat untuk reliabilitas karma memiliki korelasi $>$ dari 0,60 atau diatas $60 \%$ yaitu menunjukkan cronbach alpha 0,844.

Tabel 9. Hasil Uji Reliabilitas Tingkat

Bagi Hasil (X2)

\begin{tabular}{|c|c|}
\hline \multicolumn{2}{|c|}{ Reliability Statistics } \\
\hline $\begin{array}{c}\text { Cronbach's } \\
\text { Alpha }\end{array}$ & N of Items \\
\hline .719 & 5 \\
\hline
\end{tabular}

Sumber: Pengolahan Data Hasil Penelitian, 2018

SYARIKAT : Jurnal Rumpun Ekonomi Syariah Volume 1, Nomor 2, Desember 2018 
Setelah dilakukan pengujian reliabilitas pada variabel Mudharabah terlihat bahwa koefisien reliabilitas instrument Mudharabah (X2) memenuhi syarat untuk reliabilitas karma memiliki korelasi > dari 0,60 atau diatas 60\% yaitu menunjukkan cronbach alpha 0,719 .

Tabel 10. Hasil Uji Reliabilitas Minat Masyarakat (Y)

\begin{tabular}{|c|c|}
\hline \multicolumn{2}{|c|}{ Reliability Statistics } \\
\hline $\begin{array}{c}\text { Cronbach's } \\
\text { Alpha }\end{array}$ & N of Items \\
\hline .762 & 5 \\
\hline
\end{tabular}

Sumber : Pengolahan Data Hasil Penelitian, 2018

Setelah dilakukan pengujian reliabilitas pada variabel Mudharabah terlihat bahwa koefisien reliabilitas instrument Mudharabah (X2) memenuhi syarat untuk reliabilitas karma memiliki korelasi > dari 0,60 atau diatas 60\% yaitu menunjukkan cronbach alpha 0,762.

\section{d) Perumusan Model Regresi}

Pengolahan data ini menggunakan multiple regretion dengan bantuan program SPSS (Statistical Product Service
Solution) 16.0 dalam melakukan regresi dilakukan dengan metode enter.

Pada metode enter semua variabel independen digunakan sebagai predictor atas kriteria dalam penelitian ini. Tidak ada variabel yang dikeluarkan. Dengan demikian semua variabel independen digunakan dalam penelitian ini untuk menentukan pengaruh terhadap variabel dependen. Gambaran umum hasil analisis regresi dengan metode enter dapat dilihat pada tabel dibawah ini:

Tabel 11. Variabel Entered/Removed

\begin{tabular}{|c|c|c|c|}
\hline \multicolumn{4}{|c|}{ Variables Entered/Removed } \\
\hline Model & $\begin{array}{c}\text { Variables } \\
\text { Entered }\end{array}$ & $\begin{array}{c}\text { Variables } \\
\text { Removed }\end{array}$ & Method \\
\hline 1 & TMD, TPM ${ }^{\text {T }}$ & $\cdot$ & Enter \\
\hline a. All requested variables entered. & \\
\hline \multicolumn{3}{|c|}{ b. Dependent Variable: TMM } & \\
\hline
\end{tabular}

Sumber: Pengolahan Data Hasil Penelitian, 2018

Dari tabel diatas dapat dilihat bahwa variabel X1 adalah TPM (pendapatan masyarakat) dan X2 adalah TMD (Mudharabah)

Tabel 12. 10 Hasil Pengujian Hipotesis

\begin{tabular}{|c|c|c|c|c|c|c|}
\hline \multicolumn{7}{|c|}{ Coefficients $^{a}$} \\
\hline \multirow{2}{*}{\multicolumn{2}{|c|}{ Model }} & \multicolumn{2}{|c|}{$\begin{array}{l}\text { Unstandardized } \\
\text { Coefficients }\end{array}$} & \multirow{2}{*}{ 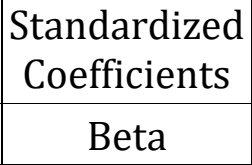 } & \multirow[b]{2}{*}{$\mathrm{T}$} & \multirow[b]{2}{*}{ Sig. } \\
\hline & & B & Std. Error & & & \\
\hline \multirow[t]{3}{*}{1} & (Constant) & 9.028 & 1.704 & & 5.298 & .000 \\
\hline & TPM & .149 & .077 & .167 & 1.936 & .056 \\
\hline & TMD & .438 & .070 & .540 & 6.265 & .000 \\
\hline a. & endent Vari & TMM & & & & \\
\hline
\end{tabular}

Sumber: Pengolahan Data Hasil Penelitian, 2018

SYARIKAT : Jurnal Rumpun Ekonomi Syariah Volume 1, Nomor 2, Desember 2018 
Persamaan regresi dari hasil perhitungan statistic didapat sebagai berikut:

$\mathbf{Y}=9,028+0,149 \mathrm{X} 1+0,438 \mathrm{X} 2+\mathrm{e}$

Hasil Regresi Linier Sederhana diatas menunjukkan bahwa variabel pendapatan masyarakat dan Mudharabah berpengaruh positif terhadap variabel minat masyarakat. Dengan demikian dapat ditarik kesimpulan bahwa, jika pendapatan masyarakat dan tingkat Mudharabah meningkat maka minat masyarakat akan meningkat.

\section{e) Koefisien Determinasi (R)}

Tabel 13. Model Summary

\begin{tabular}{|c|c|c|c|c|c|c|c|c|c|c|}
\hline \multicolumn{11}{|c|}{ Model Summary } \\
\hline \multirow[b]{2}{*}{$\begin{array}{l}\text { Mo } \\
\text { del }\end{array}$} & \multirow{2}{*}{\multicolumn{2}{|c|}{$\mathrm{R}\left|\begin{array}{c}\mathrm{R} \\
\text { Squa } \\
\mathrm{re}\end{array}\right|$}} & \multirow[b]{2}{*}{$\begin{array}{l}\text { Adjust } \\
\text { ed R } \\
\text { Square }\end{array}$} & \multirow[b]{2}{*}{$\begin{array}{l}\text { Std. Error } \\
\text { of the } \\
\text { Estimate }\end{array}$} & \multicolumn{5}{|c|}{ Change Statistics } & \multirow{2}{*}{$\begin{array}{c}\text { Durbi } \\
\text { n- } \\
\text { Watso } \\
n\end{array}$} \\
\hline & & & & & $\begin{array}{l}\text { R Square } \\
\text { Change }\end{array}$ & $\begin{array}{c}\mathrm{F} \\
\text { Chang } \\
\mathrm{e}\end{array}$ & $\begin{array}{c}\mathrm{df} \\
1\end{array}$ & $\begin{array}{l}\mathrm{df} \\
2\end{array}$ & \begin{tabular}{|c|} 
Sig. F \\
Chang \\
e
\end{tabular} & \\
\hline 1 & $\begin{array}{r}.62 \\
5^{\mathrm{a}}\end{array}$ & .390 & .377 & 1.68965 & .390 & 31.012 & 2 & 97 & .000 & 1.700 \\
\hline \multicolumn{4}{|c|}{$\begin{array}{l}\text { a.Predictors:(Constan } \\
\text { t),mhrabh, pdPT.n }\end{array}$} & & & & & & & \\
\hline \multicolumn{4}{|c|}{$\begin{array}{l}\text { b.Dependent } \\
\text { Variable: minat }\end{array}$} & & & & & & & \\
\hline
\end{tabular}

Sumber: Pengolahan Data Hasil Penelitian, 2018

Berdasarkan 13 diperoleh nilai $\mathrm{R}$ sebesar 0,625 atau $62,5 \%$ dan nilai $\mathrm{R}$ Square sebesar 0,390 atau 39\%. Hal ini menunjukkan terdapat hubungan secara erat antara variabel independen dengan variabel dependen karena nilai $\mathrm{R}$ Square sebesar 39\% pendapatan masyarakat dan tingkat Mudharabah mempengaruhi minat masyarakat menabung.

\section{f) Analisis Uji Asumsi Klasik}

\section{Uji Multikoleniaritas}

Hasil uji multikoleniaritas dapat dilihat pada tabel XIV dibawah ini:

Table 14. Hasil Uji Multikoleniaritas

\begin{tabular}{|l|c|c|c|}
\hline \multicolumn{1}{|c|}{ Variabel } & Tolerance & VIF & Keterangan \\
\hline Pendapatan Masyarakat & 0,847 & 1,181 & Bebas \\
\hline Bagi Hasil (Mudharabah) & 0,847 & 1,181 & Bebas \\
\hline
\end{tabular}

Sumber: Pengolahan Data Hasil Penelitian, 2018

Pada tabel 14 dapat disimpulkan bahwa semua variabel independent bebas dari multikolinearitas dan layak untuk digunakan dikarnakan nilai tolerannya tidak melebihi angka 1 dan nilai VIF tidak melebihi 10.

SYARIKAT : Jurnal Rumpun Ekonomi Syariah Volume 1, Nomor 2, Desember 2018 
2. Uji Autokorelasi (Uji DurbinWatson)
Hasil uji Autokorelasi dapat dilihat pada tabel berikut ini:

Table 15. Hasil Uji Autokorelasi

\begin{tabular}{|l|c|r|r|r|r|r|}
\hline \multicolumn{7}{|c|}{ Model Summary } \\
\hline Model & R & R Square & $\begin{array}{c}\text { Adjusted R } \\
\text { Square }\end{array}$ & $\begin{array}{c}\text { Std. Error of the } \\
\text { Estimate }\end{array}$ & \multicolumn{2}{|c|}{ Durbin-Watson } \\
\hline 1 & $.625^{\mathrm{a}}$ & .390 & .377 & 1.68965 & & \\
\hline $\begin{array}{l}\text { a. Predictors: (Constant), mdhrabh, } \\
\text { pdPT.n }\end{array}$ & & & & & \\
\hline
\end{tabular}

Sumber: Pengolahan Data Hasil Penelitian, 2018

Pada tabel 15 terlihat bahwa angka Durbin Watson dibawah 2 yaitu sebesar 1,700 yang berarti tidak ada autokorelasi. Dan dapat sisimpulkan bahwa regresi ini baik karna bebas dari autikorelasi.
3. Uji Heteroskedastisitas

Hasil uji Heteroskedastisitas dapat terlihat pada gambar dibawah ini:

\section{Gambar 2. Regression Studentized Residual}

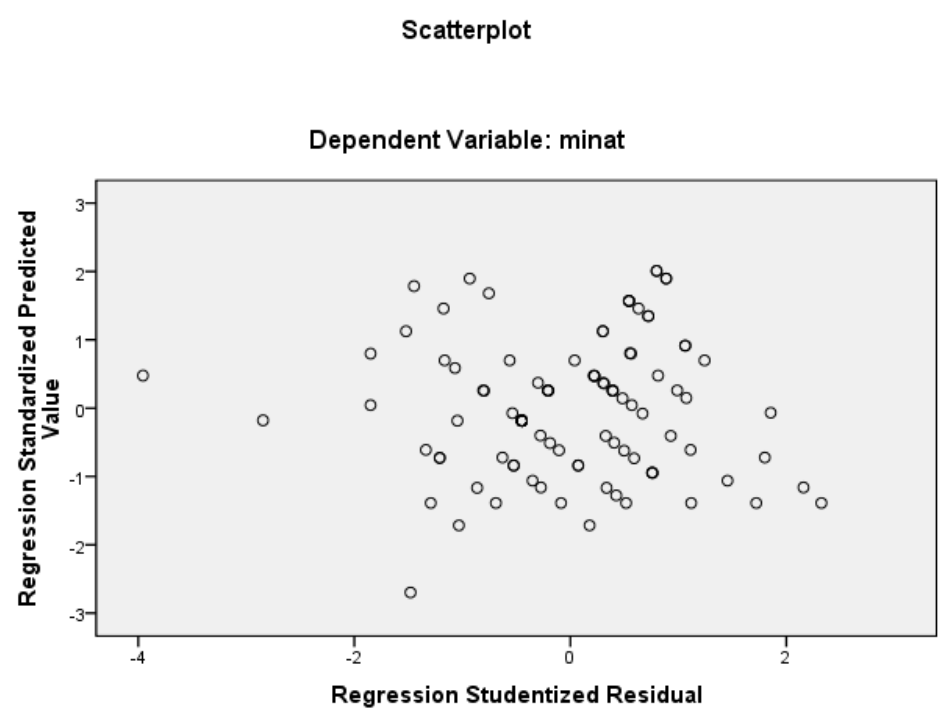

Sumber: Pengolahan Data Hasil Penelitian, 2018

SYARIKAT : Jurnal Rumpun Ekonomi Syariah Volume 1, Nomor 2, Desember 2018 
Pada gambar 2 tidak terihat pola yang jelas karna titik menyebar diatas dan dibawah angka 0 pada sumbu $Y$, sehingga dapat dikatakan bahwa pada model regresi ini tidak terjadi gejala heteroskedastisitas.

\section{g) Hasil Uji Regresi Secara Simultan}

Hasil uji regresi secara simultan atau uji F dapat dilihat pada tabel dibawah ini:

Tabel 16. Hasil Uji F Hitung

\begin{tabular}{|c|c|c|c|c|c|c|}
\hline \multicolumn{7}{|c|}{ ANOVA $^{\mathrm{b}}$} \\
\hline \multicolumn{2}{|c|}{ Model } & $\begin{array}{c}\text { Sum of } \\
\text { Squares }\end{array}$ & Df & $\begin{array}{l}\text { Mean } \\
\text { Square }\end{array}$ & $\mathrm{F}$ & Sig. \\
\hline \multirow[t]{3}{*}{1} & Regression & 177.073 & 2 & 88.537 & 31.012 & $.000^{\mathrm{a}}$ \\
\hline & Residual & 276.927 & 97 & 2.855 & & \\
\hline & Total & 454.000 & 99 & & & \\
\hline \multicolumn{4}{|c|}{ a. Predictors: (Constant), mdhrabh, pdPT.n } & & & \\
\hline \multicolumn{3}{|c|}{ b. Dependent Variable: minat } & & & & \\
\hline
\end{tabular}

Sumber : Data Olahan SPSS , 2018

Pada tabel 16 hasil regresi menunjukkan bahwa nilai $\mathrm{F}$ hitung sebesar 31,012 > F tabel sebesar 3,090 dengan nilai signifikan probabilitas sebesar $0,000<\alpha=$ 0,05 maka hipotesis penelitian diterima.

Maka, model regresi menunjukkan bahwa secara bersama-sama pendapatan masyarakat dan bagi hasil (Mudharabah) berpengaruh terhadap minat masyarakat menabung pada PT. Bank Muamalat Indonesia Tbk Cabang Pekanbaru.

\section{SIMPULAN}

Adapun kesimpulan dari tulisan ini, antara lain:

1. Pendapatan dan bagi hasil yang mendorong minat masyarakat menabung pada PT. Bank Muamalat Indonesia Tbk Cabang Pekanbaru. Semakin besar tingkat pendapatan maka semakin tinggi minat masyarakat untuk menabung. Tetapi apabila pendapatannya sedikit masyarakat belum dapat memastikan apakah menabung atau tidak. Sedangkan pada bagi hasil, apabila tingkat bagi hasil semakin tinggi atau tingkat bagi hasil mendatangkan kepuasan bagi nasabah maka semakin tinggi minat menabung masyarakat, begitu juga sebaliknya.

2. Variabel yang dominan berpengaruh terhadap minat menabung masyarakat pada PT. Bank Muamalat Indonesia Tbk Cabang Pekanbaru adalah variabel tingkat pendapatan. Berdasarkan hasil penelitian dimana alasan dan motivasi yang utama yang mendorong minat menabung masyarakat adalah tingkat pendapatan dinyatakan oleh 54 orang responden atau $54 \%$, lalu bagi hasil yang diberikan dinyatakan oleh 40 orang responden atau $40 \%$ serta pelayanan dan fasilitas yang diberikan menyatakan hanya 6 orang saja atau 6\% dari 100 orang responden yang diteliti. 
3. Secara umum hasil pengujian validitas dan reliabilitas item penyataan penelitian telah memberikan hasil yang baik. Koefisien reliabilitas menunjukkan nilai cronbach's alpha 0,604-0,854. Pengujian validitas terhadap seluruh item pernyataan dengan menggunakan corrected item-total correlation menunjukkan bahwa item-item pernyataan dinyatakan valid.

4. Normalitas rata-rata jawaban responden yang menjadi data dalam penelitian ini dilihat dari Kolmogorov-Smirnov yang menunjukkan bahwa jawaban responden terdistribusi secara normal.

5. Hasil regresi secara parsial menunjukkan bahwa variabel minat masyarakat menabung secara statistik thitung $<t_{\text {tabel }}$ yaitu untuk X1 $1,936<3,090$ dan untuk X2 6,265 > 3,090, maka X1 ditolak dan X2 diterima. Hasil menunjukkan bahwa pendapatan masyarakat tidak signifikan berpengaruh terhadap minat masyarakat menabung dan tingkat bagi hasil (Mudharabah) secara signifikan berpengaruh terhadap minat masyarakat menabung. Dimana nilai signifikan probabilitas sebesar 0,00 berada dibawah 0,05. Berdasarkan asumsi diatas jika sig < maka model ini diterima.

\section{DAFTAR RUJUKAN}

Antonio. M. (2001). .Bank Syariah dari Teori dan Praktek. Jakarta: Gema Insani

Kasmir. (2002). Bank dan lembaga Keuangan. Jakarta: Raja Grafindo Persada. . (2007). Manajemen perbankan. Raja Grafindo. Jakarta: Persada.

Sumarni, M. (2002). Manajemen Pemasaran Bank. Yogyakarta: Liberty.

Sadono. S. (2000). Makro Ekonomi Modern. Jakarta: PT. Raja Grafindo Perkasa.

Umar. H. (2002). Riset Pemasaran dan Perilaku Konsumen. Jakarta: Pustaka Utama. 